Article

\title{
Environmental Protection in School Curricula: Polish Context
}

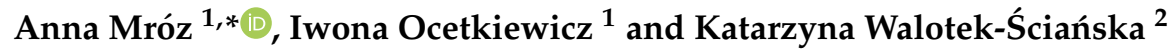 \\ 1 Faculty of Pedagogy, Pedagogical University of Cracow, Podchorążych 2, 30-084 Kraków, Poland; \\ iwona.ocetkiewicz@up.krakow.pl \\ 2 Faculty of Philosophy, Jesuit University Ignatianum in Krakow, Mikołaja Kopernika 26, 31-501 Kraków, \\ Poland; katarzynaws@interia.pl \\ * Correspondence: anna.mroz@up.krakow.pl
}

Received: 30 September 2018; Accepted: 29 November 2018; Published: 3 December 2018

check for updates

\begin{abstract}
Properly planned and effectively implemented education provides an opportunity to change human behavior, which in turn may lead to an improved quality of life worldwide, including by means of realizing a cleaner environment. This article presents the results of research on the integration of environmental protection issues into curricula by Polish teachers. It was assumed that the environmental protection issues included the challenges related to the sustainable management of natural resources. The sample consisted of 337 teachers of general subjects who were employed in schools in the Małopolska region (southern Poland) and working with students in lower-secondary (13-16 years old) and upper-secondary (16-20 years old) schools. The results of the research show that many teachers know how to integrate environmental protection issues into their curricula. However, there are still many teachers who ignore key issues in the education of sustainable development in their teaching process.
\end{abstract}

Keywords: education for sustainable development; environmental protection; curriculum; teacher; renewable resources

\section{Introduction}

\subsection{EnvironmentalProtection in the Educational Context}

The second half of the 20th century and beginning of the 21st is undoubtedly a time of great ecological crisis, the results of which may be disastrous for present and future generations. Uncontrolled globalization and the introduction of new technologies, many of which have forever changed the methods of manufacturing basic goods and services, have resulted in the destruction of ecosystems and the degradation of the natural environment, threatening life on Earth. The massive consumption of fossil fuels has caused visible damage to the environment in various forms. Approximately $90 \%$ of the energy we consume comes from fossil fuels [1]. One of the causes of this dangerous ecological crisis is the overexploitation of natural resources and the neglect of the needs of the natural environment. This is why perhaps the most important issue of our time is how to sustain our planet's resources while still developing the wealth and well-being of a growing population [2].

Often, the behaviors which lead to environmental damage are the result of human ignorance which, in turn, is a consequence of the lack of well-planned and effective education in the area of environmental protection (involving, first of all, the responsible use of natural resources and sustainable management of renewable energy resources). An attempt to compensate for this is a worldwide sustainable development concept which originates from concerns about the future world and the desire for better conditions for future generations. As an idea, sustainable development had 
already been espoused in the World Conservation Strategy (WCS), a document produced in 1980 by the International Union for the Conservation of Nature, World Wildlife Fund (now the Worldwide Fund for Nature) and the United Nations Environmental Programme [3]. The idea of sustainable development is promoted and supported by education for sustainable development, also called education for sustainability, environmental education, and sustainability education. Implementation of its principles in a didactic process should, first of all, ensure the harmonious (understood as undelayed, applied correctly and at the right time in all spheres of development) development of students and enable them to face new challenges in the future. According to the sustainable development paradigm, a well-designed education process shapes key competencies which will allow students to develop harmoniously, function actively in the present, as well as make responsible decisions and support the sustainable development of society in the future.

Education is an important element of the enhancement of pupils' environmental awareness. This is because education plays an important role in shaping and transforming society [4]. The concept of education for sustainable development (ESD) was outlined in the Agenda 21 document created during the Earth Summit in 1992, section IV-titled Means of Implementation-in chapter 36: Promoting education, public awareness and training in the area of balanced and sustainable development and environmental protection. In this document, education is considered the key factor in the implementation of sustainable development principles. Since then, there have been many documents and publications addressing the principles of education for sustainable development, including its objectives, the means of implementation, and recommended methods and forms of work.

It states in the Agenda and in documents related to the Decade of Education for Sustainable Development that education, raising public awareness, and additional training of people around the world-by means of formal, informal, and non-formal methods-are critical areas of activity for sustainable development. Suitable educational initiatives and the introduction of the new education model to schools will enable the sustained and harmonized development of humanity and, in consequence, the world. Additionally, it was declared that education worldwide must shift toward the issues of balanced and sustainable development and environmental protection [5]. It was emphasized that education-institutionalized education, in particular-should be recognized as a process by which human beings and societies can reach their fullest potential. It should also be integrated into all disciplines by employing different didactic methods and effective means of communication.

In 2015, a new plan for the implementation of sustainable development principles was developed-Agenda 2030 — which set 17 Sustainable Development Goals to achieve and 169 targets to meet by 2030 on a global scale. These objectives address five areas, the so-called 5xP: people, planet, prosperity, peace, and partnership. The goals cover a wide range of challenges, such as poverty, hunger, health, education, gender equality, climate changes, sustainable development, peace, and social justice [6]. They succeeded the Millennium Development Goals, which were to be achieved by 2015.

Education for sustainable development is commonly understood as education that encourages changes in knowledge, skills, values, and attitudes to enable a more sustainable and just society for all. ESD aims to empower and equip present and future generations to meet their needs using a balanced and integrated approach to the economic, social, and environmental dimensions of sustainable development [7].

Education for a sustainable future is a huge challenge for education systems. It requires the following questions to be addressed: How can we better understand the complexity of our world? How are the problems of today's world interrelated, and what do they mean to the people who try to solve them? What kind of world do we want in the future? Does this vision fit within the systems sustaining life on Earth? How can we reconcile the requirements of the economy, societies, and the environment? The idea of ESD is the commitment to achieving a balance between social and economic well-being, and between culture and tradition and the protection of natural resources. ESD emphasizes 
the need to respect human dignity, honor diversity, and protect the natural environment and natural resources on our planet [8-11].

The scope and diversity of current environmental issues have made it necessary to define several problem areas-such as the use of natural resources, pollution, health and nutrition, urban areas, etc.-while paying due attention to geographical, ecological, and economic variations [10]. Investigating knowledge, perceptions, as well as attitudes of the public toward various aspects of environmental issues is of great importance to the promotion of sustainable development [12-14]. It is worth emphasizing that these issues have long been present in environmental education (EE). However, only since the 1970s has there been a shift toward a more holistic approach to EE content and the target group. Now, EE aims to create a population that not only is knowledgeable but also shows positive attitudes and takes action to preserve the environment. According to ESD principles, it is not only ecological education that should address important environmental issues. These problems should be discussed during the teaching of all subjects and at every stage of child and youth education.

The term "environmental protection" includes, among others, the postulate of the sustainable management of natural resources.

Sir Ken Robinson noticed that curricula set out frameworks of what students should know, understand, and be competent to do. In most schools, some parts of the program are obligatory, others are optional, and some are voluntary, like extracurricular activities. Curricula can be formal and informal. A formal program is obligatory, with grades and exams, while an informal component includes voluntary activities [15]. Teachers, then, have much freedom in selecting non-obligatory, voluntary content. They can also, to some extent, choose the content and issues for the obligatory parts (for example, the subjects of home assignments, presentations, or readings during foreign language classes). Curricula allow for addressing certain issues in many ways. The author of the Second Collection of Good Practices Education for Sustainable Development UNESCO Associated Schools 2009 [16] emphasizes that Ministries of Education worldwide examine how to introduce and reinforce key sustainability issues throughout the curricula, in the training of teachers, in extracurricular activities, and in non-formal education (p. 5). It is a very important issue-from the point of view of educational practices but also globally—as it may influence the future condition of our world. The Global Action Programme on Education for Sustainable Development also underscores the integration of key sustainable development issues in school curricula [17].

\subsection{The Teacher's Role in the Challenges of Modern Education}

Ongoing social changes have impacted the vision of the professional role of teachers. The desired professional roles of a teacher working with adolescents and implementing sustainable development education principles are those of a guide, an interpreter, a researcher, a reflective practitioner, an emancipated teacher, a transformative intellectualist, and a post-positivist practitioner [18].

Teachers as guides fulfill their role by showing students new areas of knowledge and setting directions toward which they will lead the students. They are also translators of a complex, diverse, and multi-voice culture; they explain the sources, meanings, and potential consequences of different phenomena. They explain the possible choices that arise in individual and unique ways that advance identity development and suggest ways of dealing with struggles in a multicultural world [18].

As researchers, teachers know that educational investigations should be an integral part of their work. As stated by Stanisław Palka, the "teaching profession forces to assume the role of pedagogical researcher, as teachers must diagnose, explain and make decisions based on, among others, the results of their conversations with students, other teachers and parents, document analysis and analysis of class test and didactic test results" [19]. While studying their own activities, teachers should focus on the teaching process as it connects with discovery and exploration, as well as with the facilitation and improvement of the cognitive activity of students. In this way, teachers may become participants, creators, and competent observers of educational events. 
Teachers in the role of reflective practitioners build their competencies based on their own practical experience. The idea of reflective practice originated from the studies by an American epistemologist, Donald Schön, who analyzed competencies of professionals in the U.S. during atime of decreasing social trust toward this profession. He presented his theory in the book The Reflective Practitioner: How Professionals Think in Action, published in 1987 [20]. Reflection-in-action became Schön's main focus. He called itthe "experimenting" that takes place in current situations-problematic and uncertain-which differ from previous ones. The goal of reflection-in-action is to change the situation. According to Schön [20], when reflective practitioners try to understand a given situation, they effect a change, which increases their awareness. It is a sequence: understanding inaction, followed by a "reflective spiral". Spontaneous but also smooth and on-the-spot action results from the knowledge found within oneself. It is knowing-in-action which is hard to articulate, but once finished, it can be subject to reflection. Schön explains that reflective practitioners have the ability to see unfamiliar situations as familiar ones and to act as they have in similar circumstances. He calls it "see-as" and "do-as". When reflecting in action, on action, and about action, teachers engage in the active search for solutions, the aim of which is not only to better understanding theself but also to improve their own work. They must constantly update their professional situations and be researchers oftheir own practice, approaching certain situations as research problems and integrating their thinking and doing into thesearch forsolutions, formulating their own theories independent of scientific ones. In this way, they develop their personal knowledge and own ways of acting. A teacher's reflection is a kind of thinking that accompanies doing in order to transform some elements or the whole situation. Reflective practitioners create their workshop by analyzing their own knowledge. Their professional behavior involves not only reflection in and overbut also about the action. This reflection results from acritical attitude which requires the exploration of ethical, political, and instrumental issues rooted in their daily thinking and professional practice. The value of the concept of are flective teacher practitioner is in the fact that personal experience is treated as the source of knowledge necessary to fulfill professional duties. By trusting their own experiences, teachers create their own practice and theory of this practice. Thanks to the emphasis on the subjective activity of teachers, rights and opportunities to participate in group life result from their reflective actions, as well as the actions of students oriented toward intentional adaptation or change.

Another role of teachers-emancipated teachers-is connected with understanding the typical emancipatory pedagogy of student subjectivity. The implementation of emancipatory pedagogy postulates requires respecting the principle of the subjective nature of pedagogical interaction. A subjective sense of freedom is shaped and developed during the process of learning and doing, and its starting point is within personal experience, tangible opposition, and conflict. Emancipated teachers are engaged in change. They oppose the compulsory solutions and want to search for their own alternative options which could replace the hitherto ones. They show advanced critical thinking and reflective abilities in viewing the world. Emancipated teachers are promoters of change and empowerment of education. In addition, being critical and reflective, they develop tools to modify their own practice; learn how to teach by planning constant improvements according to lifelong education postulate; master the process of discovering and creating knowledge, together with knowing the methodologies of the discipline taught and education sciences; develop the critical approaches, openness, and courage necessary to reorient education and the concept of school.

Critical pedagogy representatives, such as Paulo Freire, Henry Giroux, and Peter McLaren, postulate that teacher should be a transformative intellectual (a term coined by Henry Giroux), that is, an advocate of weaker social groups and translator between humans and the complex social world. The transformative intellectual should facilitate a critical understanding of the world, first of all by showing social inequalities [21-24]. The concept of the teacher as a transformative intellectual is rooted in a radical ideology which is contrary to conservative and liberal ideologies. The conservative ideology focuses on the education of students as future employees who need to acquire standard skills, and the role of the teacher is reduced to transmitting a socially accepted scope of knowledge. In the 
liberal ideology, personal development is the most important. It can be achieved through personal successes and awards when competing with others, and the teacher's role is to create conditions fostering the development of critical thinking in students. Teachers as transformative intellectuals should be open to the problems of human rights, the rights of minorities and marginalized people, and social inequality and exclusion; they should be sensitive to differences in public and private life and follow the road to execute resistance policy. It is worth emphasizing that these problems have been considered by UNESCO as threats to the sustainable development of the world.

The teacher as a post-positivist practitioner responds to present and future challenges. This image is the result of applying critical, postmodern social theory connected with reflective orientation in the analysis of the teacher's work. The image comprises characteristic behaviors of a postmodern teacher, including:

- $\quad$ practicing reflectiveness based on the ability to investigate one's own practice;

- connecting thinking with social and historical contexts and power aspects;

- $\quad$ improvising, thinking-in-action, responding to unexpected situations;

- modeling a culture of activity among students that allows different opinions and attitudes, prefers discussions, and is open to students' experiences and their way of thinking about the world and representing the world;

- exercising critical social and self-reflection based on the dialogue of subjects of the teaching-learning process;

- $\quad$ engaging in the development of democracy in the class and school;

- displaying an active attitude that breaks the students' tendency to passiveness and passive thinking, connecting knowledge with action;

- possessing knowledge of cultural differences in the community, respecting minority rights, cultural pluralism;

- $\quad$ including the emotional side of contact with students in the teaching process, allowing emotional behaviors like humor, compassion, empathy, and resentment in dialogues with students [18].

The model of the teacher as a post-positivist practitioner of the postmodern age is a postulative model which shows how teachers can be, rather than how they must be. These teachers follow the idea of subjectivity, emancipation, and engagement in matters of the world functioning in a democratic and sustainable way. They reject and oppose being enslaved by power, knowledge, and modernist anti-intellectualism. It is easy to notice that the above-presented models of teachers' roles are connected and overlapping. Their responsibilities are repeated and focus mainly on a reflective attitude and critical thinking [18].

All of this suggests that the primary task of modern teachers is to empower students, so they can actively and creatively transform their reality and are prepared to live valuable lives in the global information society. Teachers are responsible for preparing young people for active participation in creating a better future-their own and the world's. Therefore, the style of work is important: the methods and teaching forms, as well as the content addressed during classes, extra activities, and school trips-in other words, the content teachers include in their curricula. This content may translate into the growth of students' knowledge and their daily behaviors, choices, and attitudes and, through those aspects, into their efforts toward sustainable development in three dimensions: social, environmental, and economic.

Teachers who work with adolescents (13-20 years old) must know the needs, abilities, and limitations of their students. The period of learning in lower- and upper-secondary school is the developmental stage called early and late adolescence. In early adolescence, young people begin to search and gather new physical, social, and intellectual experiences, so they can then organize and unify them into new patterns and scenarios that best prepare them for adult life [25]. During the cognitive development of teenagers, there is a shift to formal operations. Early adolescence is marked by the increasingly more advanced implementation of the rules and laws of certain areas of 
knowledge, expressed verbally or through symbols. Formal thinking allows for going beyond what cannot be known directly; enables reasoning from the general to the particular-from hypothesis or assumption to conclusion; formulating general conclusions based on detailed facts (scientific-inductive thinking). Formal thinking is also the ability to simultaneously consider many variables (combinatory reasoning); abstract thinking reflects understanding by way of inner thoughts or reflection based on the available knowledge but reaching beyond what is observable (reflective-abstract thinking) $[25,26]$. Unlike children, teenagers are able to consider different options and possibilities. They can imagine the future consequences of their present actions; thus, they are capable of some form of long-term planning. Another characteristic of formal thinking is the search for solutions to problems in a systematic and methodical way. Thinking based on formal operations ensures compensation for imbalances in cognitive structures and adaptation by using the following logical operations: identity, negation, inverse, and reciprocity - that is, searching for one law (rule, principle) that is absolutely true regardless of the context (so-called logical absolutism). As the foundation of the hypothetico-deductive system, classical logic does not allow contradictions, which means that, during adolescence, the dominating means of resolving mental contradictions is, according to formalized thinking, the rejection of one of the alternatives. However, it is worth noticing that some approaches posit that teenagers are able to think relatively and are convinced that knowledge is relative. Adoption of relativist thinking by young people is probably easier due to their contact with social problems (active fulfillment of different and often contradicting social roles; personal motivation included in the cognitive process, etc.) and due to their received training on humanistic knowledge. In turn, frequent training on formal knowledge, such as mathematics, physics, or foreign languages, may facilitate the development of formal thinking. Thus, cognitive development is dynamic in the areas of activity specific to certain individuals. If a student often engages in solving problems from a certain knowledge area, he or she may expect their knowledge and skills in this area to become more advanced, internally connected, and viewed relatively from many perspectives $[25,26]$. During adolescence, there are also changes in (1) knowledge, (2) cognitive processes and competencies, and (3) meta cognitive orientations. Knowledge refers to the three types of information structures in long-term memory. They include declarative knowledge based on the "I know that..." scheme, covering the known facts; procedural knowledge ("I know how...") regarding all abilities focused on the goal; and conceptual knowledge ("I know why...")—understanding the declarative and procedural knowledge [25].The cognitive processes of adolescents take on different forms: inductive and deductive reasoning, analogies, decision making, and problem-solving. Other important processes refer to coding or formulating a mental representation of the learning situation, memorizing and storing information in long-term memory, and reproducing - taking information out of the long-term memory. Metacognitive orientations refer to adolescents reflecting the state of their knowledge and evaluation of this knowledge-a young person should be able to determine what they know; if they know that they do not know; and whether they tend to absolutize or relativize. Adolescence is a period of intense development of imagination that can be seen in teenagers' creativity and dreams. They tend to see reality in an original way; easily accept innovations, including technical ones; have spontaneous rationalized ideas which make their daily life easier. Their dreams, regarding both themselves and their environment, often allow them to achieve what, in reality, is out of their reach. Creative work is common among young people and is most often expressed in the form of diaries, original music, song lyrics, or poems. In the area of verbal creativity in asocial forum (e.g., editing school newsletters), girls are more active [26]. Memory also changes during adolescence. Memory development can be connected to four components: capacity, base memory processes, memorizing strategies, and metamemory. The source of these transformations are changes in the adolescent brain. On the one hand, compared to adults, young people show some weaknesses in cognitive processing, including weaknesses in the executive function of the frontal lobe, visual-spatial and verbal memory, and response time (i.e., slower). On the other hand, in early adolescence, there is already growth in the volum of memorized and stored information, especially practical information. This is possibly a result of an increased 
number of neuronal connections that form during adolescence. Ever more plastic and faster processes of recognizing, coding, filing, and searching lead to the improvement of base memory processes. The effectiveness and frequency of using memory strategies are also enhanced, along with the ability to memorize and improve metamemory [26]. During adolescence, young people need to develop their emotional-cognitive structures, which allow them to succeed in difficult situations and build proper emotional relationships with others. The most important emotional competencies teenagers need to develop are the following: regulation of the intensity of emotions, as they tend to experience extreme emotions; adaptation of the means of expressing rapidly changing (unsteady) emotions; calming down; understanding the social consequences of expressing emotions openly or hiding them; using symbolic thinking to transform negative emotions into less repulsive ones; discerning emotions from the facts that cause them; maintaining relationships with other people despite strong negative emotions; acquiring a wide range of skills in experiencing and expressing empathy; and using cognitive skills to better understand the nature and the sources of emotions. Better cognitive abilities and the search for distinctness in me-others relationships become the basis of more mature, empathetic experiences. The ability to feel empathy enables young people to feel the suffering and distress of others, even when there is no direct situational pressure. This may motivate engagement in prosocial activities and strengthen their social sensitivity. During middle and late adolescence, some additional higher feelings connected with an upheld value system or ideology are developed. The main values preferred by young people are truth, virtue, religious values, altruism, sociopolitical values underlying tolerance, justice, and others $[25,26]$. Therefore, adolescence is theperfect time to shape the knowledge and attitudes of young people, including those regarding the needs of the natural environment.

\section{Methodological Assumptions of the Research}

Our analyses focus on the problem of integrating environmental content, including the sustainable management of natural resources, into Polish curricula for students aged 13-20. We assumed that the frequency and means of addressing the critical ESD issue by teachers translate into the knowledge students have about environmental protection, which, in turn, may determine the awareness, attitudes, and, consequently, environmental behaviors of young people. We also assumed that, according to UNESCO experts' postulates, all teachers should include topics critical for ESD into their curricula. As a UN and EU member, Poland must respect the principles set in the Agenda 2030 [26] and its 17 priority goals for a sustainable future. Goal 4 is to Ensure inclusive and equitable quality education and promote lifelong learning opportunities for all [27], whereas Goal 7 is to Ensure access to affordable, reliable, sustainable and modern energy for all. We assumed that Goal 7 may be achieved through education (Goal 4). A. Leicht, J. Heiss, and W. J. Byun [6] argue that "Educational programmes, particularly non-formal and informal, can promote better energy conservation and uptake of renewable energy sources" (p. 31).

\subsection{Main Goal of the Study}

The main goal of the study isto explore ways of integrating environmental issues into curricula in lower- and upper-secondary schools (students aged 13-20). We assumed that the term nature protection means all activities to preserve animate and inanimate features of nature and landscapes in their unchanged or optimal state. The main environmental protection objective is to maintain the stability of ecosystems and ecological processes, as well as biological diversity. One of the elements of nature protection is the promotion of renewable energy sources. There is an unquestionable correlation between generating energy from traditional sources and the degradation of the natural environment. Sustainable development also refers to human activities which maintain the balance of nature and aim toprovide present and future generations with the opportunity to meet their needs and enjoy nature. Thus, it is contrary to this principle to exhaust nonrenewable resources and cause irreversible climate change (and its consequences for the environment) and dangerous air pollution. To summarize, 
sustainable development (including natural environment protection) in the context of environmental protection means-among other things-actions that promote the use of renewable energy sources.

\subsection{Method, Research Technique, and Tool}

We collected data by means of a survey (survey method) [28]. The study was performed within the quantitative paradigm [29].The use of a survey allows for the collection of answers from many respondents quickly, and respondents' declarations are precise and refer to the exact subject matterwhich is of interest to researchers. The technique used in the research was polling. In order to collect data, we used questionnaires. The tool was developed for the purposes of this particular study (see Table 1). Respondents were asked to indicate which critical sustainable developmenttopics are regularly (not occasionally or from time to time) part of their curricula, and how frequently are they introduced.

Table 1. Method, technique, and research tool used in the research.

\begin{tabular}{ll}
\hline Method & Survey \\
\hline Research technique & polling \\
\hline Tool & original questionnaire, developed for the purposes of this particular research \\
\hline
\end{tabular}

On the basis of literature review, we identified four main ways of integrating environmental protection issues into teaching programs:

(1) Covering ESD-related topics during subject lessons;

(2) Covering ESD-related topics during additional classes: for example, interest clubs;

(3) Assigning homework referring to sustainable development topics;

(4) Encouraging students to engage in out-of-school activities.

We determined the dependent and independent variables (Table 2).

Table 2. Variables determined in the research.

\begin{tabular}{ll}
\hline Dependent Variable & Independent Variables \\
\hline & - School level (gimnazjum-lower-secondary school; \\
& lyceum/technikum-upper-secondary school) \\
& - School location (village, small town, big city) \\
integrating environmental & - Years of employment (0-5, 6-10, 11-15, 16-20, 21 and more) \\
protection issues into & - Degree of professional promotion of teachers (trainee, contractual teacher, \\
school curricula & appointed teacher, chartered teacher) \\
& - Subject taught (Polish language, foreign languages, human and social sciences, \\
& science and natural sciences, mathematics, and information and \\
& technical subjects). \\
\hline
\end{tabular}

Using Pearson's chi-square test, we checked which independent variables are statistically relevant for including environmental issues in subject curricula.

\subsection{Sample and Organization of the Research}

In order to collect the research data, convenience sampling [30] was applied in accordance with the following criterion: the consent of the participants to take part in the survey. The statistical and demographic data of teachers who participated in the survey are presented in Table 3. and Figure 1. 
Table 3. Statistical and demographic data of teachers who participated in the survey.

\begin{tabular}{|c|c|c|}
\hline School location & $\mathbf{N}$ & $\%$ \\
\hline Village & 128 & 37.98 \\
\hline Small town & 136 & 40.36 \\
\hline Big city & 68 & 20.18 \\
\hline N/A & 5 & 1.48 \\
\hline School level & $\mathbf{N}$ & $\%$ \\
\hline Lower secondary & 177 & 52.52 \\
\hline Upper secondary & 149 & 44.21 \\
\hline N/A & 11 & 3.26 \\
\hline Years of employment & $\mathbf{N}$ & $\%$ \\
\hline $0-5$ years & 36 & 10.68 \\
\hline $6-10$ years & 64 & 18.99 \\
\hline $11-15$ years & 85 & 25.22 \\
\hline 16-20 years & 102 & 30.10 \\
\hline 21 years and more & 50 & 15.0 \\
\hline Degree of professional promotion & $\mathbf{N}$ & $\%$ \\
\hline Trainee & 13 & 3.86 \\
\hline Contractual teacher & 45 & 13.35 \\
\hline Appointed teacher & 82 & 24.33 \\
\hline Chartered teacher & 196 & 58.16 \\
\hline Subject taught & $\mathbf{N}$ & $\%$ \\
\hline Polish language & 60 & 17.80 \\
\hline $\begin{array}{l}\text { Human and social sciences (civil knowledge, history, knowledge about culture, } \\
\text { entrepreneurship) }\end{array}$ & 67 & 19.88 \\
\hline Foreign languages & 74 & 21.96 \\
\hline Mathematics & 36 & 10.68 \\
\hline $\begin{array}{l}\text { Science and natural sciences (biology, chemistry, physics, geography, education to } \\
\text { family life) }\end{array}$ & 86 & 25.52 \\
\hline Information and technical subjects (ITC, technics) & 9 & 2.67 \\
\hline Physical education & 1 & 0.30 \\
\hline Arts (music, visual arts) & 3 & 0.89 \\
\hline NS & 1 & 0.30 \\
\hline Total & 337 & $100 \%$ \\
\hline
\end{tabular}

Teachers were asked about the key sustainable development issues that they integrate into their curricula and the waysby which theypresent and discuss these issues. The survey was conducted from May to November 2016. Teachers of general subjects in lower- and upper-secondary schools in the Małopolskie region (voivodship) were invited to take part in the research. There were 927 questionnaires distributed, out of which 337 were completed. The survey was conducted in:

- $\quad$ the 2 biggest cities of the Małopolska region (8 lower- and 3 upper-secondary schools);

- 9 small towns (16 lower- and 14 upper-secondary schools);

- $\quad 21$ villages (19 lower- and 2 upper-secondary schools). 
For the purpose of this text, the issues of environmental protection were analyzed. Teachers were instructed that environmental protection means any action designed to remedy or prevent damage to physical surroundings or natural resources by a beneficiary's own activities, to reduce the risk of such damage, or to lead to a more efficient use of natural resources, including energy-saving measures and the use of renewable sources of energy [31].

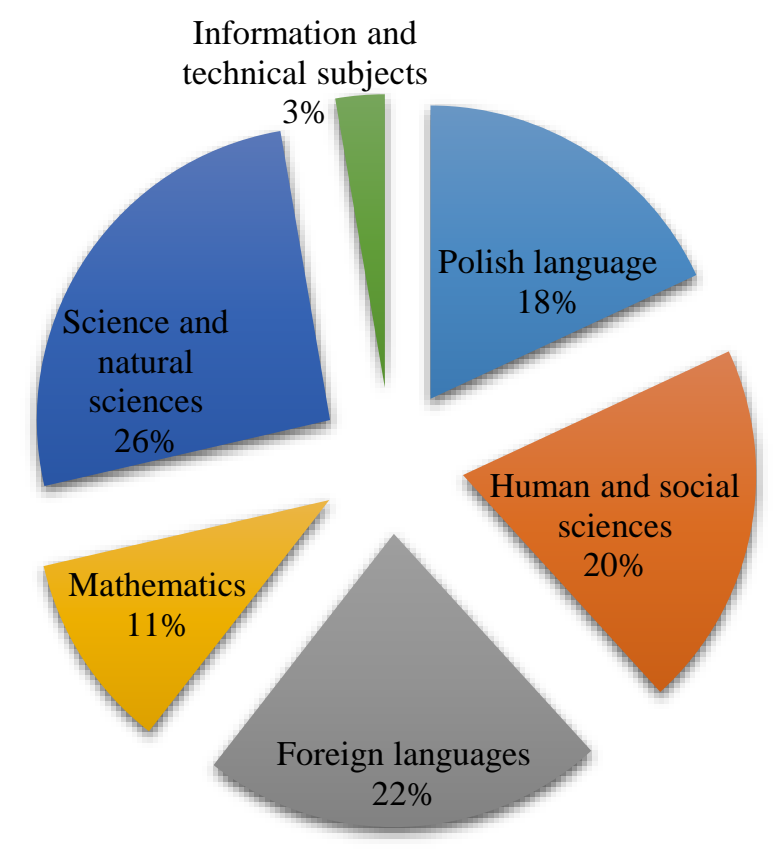

Figure 1. Percentage participation of teachers of particular subjects in the research.

The Małopolska region, where the research was carried out, is located in the central-southern part of the country. The region has 3.4 million inhabitants (as of December 2017), making it the fourth most populated region in Poland. The population density is the second highest in the country. In terms of economic development, the region is one of the most diverse in Poland. Situated at the crossing point of communication routes between the West (Austria, Germany) and the East (Ukraine) and between the North (Scandinavian countries) and the South (Slovakia, Hungary), it has exceptional assets and annually attracts 10-12 million tourists, new investments, and young people studying at regional universities. Małopolska has a high potential for scientific research and higher education-Cracow is the second center of research development in Poland. There are 32 higher-education institutions and universities, representing $7.1 \%$ of all higher-education institutions in Poland. There are over 180,000 students and more than 55,000 graduates per year. In 2013, over 25\% of entrepreneurs' spending on innovations was allocated to research and development (first place in the country). Małopolska is one of the most important Polish bioregions, with a high potential for the development of life sciences with well-developed medical facilities. This region has a high potential for energy technology research. The capital city of Małopolska-Cracow-is one of the most important industrial designer education centers in Poland. In Małopolska, there are more than 100 research and development centers, including the Foundry Research Institute, Institute of Forensic Research, Institute of Oil and Gas, and Institute of Advanced Manufacturing Technologies [32]. Due to the significant air pollution in the biggest city (Cracow), there is an ongoing debate on alternative and sustainable sources of energy. Considering the fact that Małopolska is a region with many universities, communication between scientists and the regional population is easy, and this may translate into a higher level of knowledge and awareness of the issues of environmental protection among the residents. It is a problem that affects all the residents, which, in turn, obligates teachers to search for solutions in their daily practice by, among other actions, integrating this topic into their curricula. 


\section{Research Results}

\subsection{Integrating Environmental Protection Issues into Curricula}

Our analysis indicates that teachers of all subjects are aware of the need to cover the issues of environmental protection in their curricula (Table 4). Unsurprisingly, these topics are most often introduced by science and natural science teachers (biology, physics, chemistry). It is interesting that even more foreign language teachers $(87.84 \%$ ) declare they cover environmental protection issues in their curricula. Perhaps, being aware of the principles of ESD, they try to introduce topics critical for the sustainable future of the world. We need to point out that, in Poland, there are many UNESCO resources on ESD, available in English, German, or French. This means that teachers of these subjects have easier access to the materials.

Table 4. Integration of environmental protection into curricula by teachers of various subjects.

\begin{tabular}{ccccccc}
\hline $\begin{array}{c}\text { Polish } \\
\text { Language }\end{array}$ & $\begin{array}{c}\text { Humanities } \\
\text { and Social } \\
\text { Sciences }\end{array}$ & $\begin{array}{c}\text { Foreign } \\
\text { Languages }\end{array}$ & Mathematics & $\begin{array}{c}\text { Natural } \\
\text { Sciences }\end{array}$ & $\begin{array}{c}\text { Information } \\
\text { and Technical } \\
\text { Subjects }\end{array}$ & Total \\
\hline$\%$ & $\%$ & $\%$ & $\%$ & $\%$ & $\%$ & $\%$ \\
\hline 60.00 & 59.7 & 87.84 & 63.89 & 86.06 & 55.56 & 73.59 \\
\hline
\end{tabular}

The study reveals a small difference between the declarations made by lower- and upper-secondary school teachers. Slightly more teachers working in lower-secondary education teach ESD-related topics. This may be due to the fact that lower-secondary school teachers are not pressured by the need to prepare students formatriculation exams and can spend more time on additional topics critical for the future of our world and for ensuring a better quality of life for future generations. The results of analyses of dependencies between education level taught and whether environmental protection issues are addressed during classes are presented in Table 5.

Table 5. Integration of environmental protection into curricula and level of education taught.

\begin{tabular}{ccc}
\hline Lower Secondary & Upper Secondary & Total \\
\hline$\%$ & $\%$ & $\%$ \\
\hline 78.53 & 67.11 & 73.59 \\
\hline
\end{tabular}

During the analysis, we noticed the following relation (see Table 6): the more years of employment, the higher the percentage of teachers declaring that they integrate environmental protection issues into their curricula. Therefore, if teachers with more professional experience are more willing to include environmental protection issues into their curricula, this may indicate that teachers with greater professional experience have greater knowledge about the principles of ESD and are more willing to integrate its key topics into their curricula.

Table 6. Integration of environmental protection into curricula and years of employment.

\begin{tabular}{cccccc}
\hline $\mathbf{0 - 5}$ & $\mathbf{6 - 1 0}$ & $\mathbf{1 1 - 1 5}$ & $\mathbf{1 5 - 2 0}$ & $\mathbf{2 1}$ and more & Total \\
\hline$\%$ & $\%$ & $\%$ & $\%$ & $\%$ & $\%$ \\
\hline 58.33 & 59.38 & 78.82 & 80.26 & 91.16 & 73.59 \\
\hline
\end{tabular}

There are five stages of teacher promotion in Poland: university graduates become "trainees" who teach for 1-2years. After few years of work, a trainee can become a "contractual teacher". After passing an examination, he/she can attain the status of "appointed teacher". The fourth level— "chartered teacher" - is the last level for most teachers. Some, however, manage to reach the fifth, honorary level, 
which is "professor of education". Surprisingly, the stage of professional promotion connected with the number of years of employment has no obvious influence on whether or not teachers integrate environmental protection issues into their curricula (Table 7). Of the five professional tiers, the highest proportion of teachers indicating their coverage of these topics in their classes is the group of chartered teachers (almost 80\%). The differences between teachers in the other stages are minor.

Table 7. Integration of environmental protection into curricula and stage of teachers' professional promotion.

\begin{tabular}{ccccc}
\hline Trainee & Contractual Teacher & Appointed Teacher & Chartered Teacher & Total \\
\hline$\%$ & $\%$ & $\%$ & $\%$ & $\%$ \\
\hline 69.23 & 64.44 & 65.85 & 79.08 & 73.59 \\
\hline
\end{tabular}

Bigger differences are visible between teachers working in different locations-most often, environmental protection issues are addressed by educators in villages, while they are taught slightly less frequently in small towns and cities (Table 8).

Table 8. Location of the school and integration of environmental protection into curricula.

\begin{tabular}{cccc}
\hline Village & Small Town & Big City & Total \\
\hline$\%$ & $\%$ & $\%$ & $\%$ \\
\hline 80.47 & 69.12 & 70.59 & 73.59 \\
\hline
\end{tabular}

\subsection{Ways of Integrating Environmental Protection Issues into Curricula}

Teachers who declared that they integrate topics related to environmental protection into their curriculum were asked to indicate how they introduce them in their work and how often they do it. Analysis of the results shows that the variable subject taught has the greatest influence on the way that environmental protection issues are integrated.

About $60 \%$ of the teachers declaring that they address the issue of environmental protection during their classes very often do soby discussing the topic during their subject lessons. What is surprising is that a very similar percentage of foreign language and science and natural sciences teachers declared that they use this method very often $(68.92 \%$ and $69.77 \%$, respectively-see Table 9$)$. This means that it is not only the teachers of science and natural sciences who effectively incorporate issues and topics related to the environment into their daily work: foreign language teachers also willingly address these topics with their students.

Table 9. Covering ESD-related topics during subject lessons and subject taught.

\begin{tabular}{cccccccc}
\hline & $\begin{array}{c}\text { Polish } \\
\text { Language }\end{array}$ & $\begin{array}{c}\text { Humanities } \\
\text { and Social } \\
\text { Sciences }\end{array}$ & $\begin{array}{c}\text { Foreign } \\
\text { Languages }\end{array}$ & Mathematics & $\begin{array}{c}\text { Natural } \\
\text { Sciences }\end{array}$ & $\begin{array}{c}\text { Information } \\
\text { and Technical } \\
\text { Subjects }\end{array}$ & $\begin{array}{c}\text { Total } \\
\text { Never }\end{array}$ \\
\hline $3.33 \%$ & $4.48 \%$ & $4.05 \%$ & $11.11 \%$ & $0.00 \%$ & $0.00 \%$ & $3.56 \%$ \\
\hline Occasionally & $1.67 \%$ & $2.99 \%$ & $1.35 \%$ & $13.89 \%$ & $3.49 \%$ & $0.00 \%$ & $4.15 \%$ \\
\hline Sometimes & $35.00 \%$ & $29.85 \%$ & $25.68 \%$ & $30.56 \%$ & $26.74 \%$ & $44.44 \%$ & $29.08 \%$ \\
\hline Very often & $60.00 \%$ & $62.69 \%$ & $68.92 \%$ & $44.44 \%$ & $69.77 \%$ & $55.56 \%$ & $63.20 \%$ \\
\hline
\end{tabular}

Of all the teaching disciplines, the lowest proportion of teachers who declared that they address environmental protection issues during their lessons are the mathematicians. One in 10respondents never do it; almost $15 \%$ do it occasionally; one-third indicated "sometimes", and $44.44 \%$ chose "very often". Teachers of Polish and other human and social sciences include these topics among the problems discussed during their classes.

Another applied method of teaching environmental protection principles is by addressing them during additional classes, e.g., interest clubs. We need to point out that, in Poland, extra classes in 
schools are not popular. Teachers are not obliged by the law or school managers to engage in additional activities. Some of them, especially when they apply for promotion, decide to lead extra classes. It also depends on school policy-sometimes, directors go to great effort to offer as many extra activities as possible.

The above approach turns out to be a much less popular method of integrating environmental issues into school the curricula (Table 10). About one-fifth of Polish, foreign languages, social and human sciences teachers and one-fourth of science and natural sciences teachers impart ESD principles in this way. Only 1in 10mathematicians or ICT and technics teachers address these issues very often during additional classes. It is noteworthy that as many as one-fourth of surveyed mathematicians never discuss environmental protection issues during their extra classes. Similarly, almost $20 \%$ of Polish teachers declared that they never address these problems in their additional classes. About $10 \%$ of human and social sciences, foreign language, and natural sciences teachers never address these issues during the extra classes they lead.

Table 10. Covering education for sustainable development (ESD)-related topics during additional classes, e.g., interest clubs, and subjects taught.

\begin{tabular}{|c|c|c|c|c|c|c|c|}
\hline & $\begin{array}{c}\text { Polish } \\
\text { Language }\end{array}$ & $\begin{array}{c}\text { Humanities } \\
\text { and Social } \\
\text { Sciences }\end{array}$ & $\begin{array}{c}\text { Foreign } \\
\text { Languages }\end{array}$ & Mathematics & $\begin{array}{l}\text { Natural } \\
\text { Sciences }\end{array}$ & $\begin{array}{c}\text { Information } \\
\text { and Technical } \\
\text { Subjects }\end{array}$ & Total \\
\hline Never & $18.33 \%$ & $10.45 \%$ & $12.16 \%$ & $25.00 \%$ & $12.79 \%$ & $0.00 \%$ & $13.95 \%$ \\
\hline Occasionally & $11.67 \%$ & $14.93 \%$ & $18.92 \%$ & $22.22 \%$ & $19.77 \%$ & $44.44 \%$ & $18.10 \%$ \\
\hline Sometimes & $48.33 \%$ & $53.73 \%$ & $45.95 \%$ & $41.67 \%$ & $40.70 \%$ & $44.44 \%$ & $45.70 \%$ \\
\hline Very often & $21.67 \%$ & $20.90 \%$ & $22.97 \%$ & $11.11 \%$ & $26.74 \%$ & $11.11 \%$ & $22.26 \%$ \\
\hline
\end{tabular}

Teachers may implement the principles of environmental protection by assigning homework. However, it turns out that this is not a popular way of integrating these issues into curricula (Table 11). Almost $40 \%$ of mathematicians never do it. One-fifth of Polish language teachers declared that they never give home assignments connected with the issues of environmental protection (very often—only $5 \%$ ). Teachers of subjects usually associated with this area-science and natural sciences—only sometimes $(40.7 \%)$ or occasionally (34.88\%) give home assignments regarding environmental protection. It is surprising because if teachers working with youths aged 13-20 want to raise students' awareness of sustainable development, they can expect that students would actually work independently at home.

Table 11. Assigning homework connected with the areas of sustainable development and subject taught.

\begin{tabular}{|c|c|c|c|c|c|c|c|}
\hline & $\begin{array}{c}\text { Polish } \\
\text { Language }\end{array}$ & $\begin{array}{l}\text { Humanities } \\
\text { and Social } \\
\text { Sciences }\end{array}$ & $\begin{array}{c}\text { Foreign } \\
\text { Languages }\end{array}$ & Mathematics & $\begin{array}{l}\text { Natural } \\
\text { Sciences }\end{array}$ & $\begin{array}{c}\text { Information } \\
\text { and Technical } \\
\text { Subjects }\end{array}$ & Total \\
\hline Never & $21.67 \%$ & $16.42 \%$ & $16.22 \%$ & $38.89 \%$ & $15.12 \%$ & $11.11 \%$ & $18.99 \%$ \\
\hline Occasionally & $23.33 \%$ & $31.34 \%$ & $32.43 \%$ & $41.67 \%$ & $34.88 \%$ & $22.22 \%$ & $31.75 \%$ \\
\hline Sometimes & $50.00 \%$ & $41.79 \%$ & $43.24 \%$ & $11.11 \%$ & $40.70 \%$ & $66.67 \%$ & $40.95 \%$ \\
\hline Very often & $5.00 \%$ & $10.45 \%$ & $8.11 \%$ & $8.33 \%$ & $9.30 \%$ & $0.00 \%$ & $8.31 \%$ \\
\hline
\end{tabular}

A quite popular method of introducing environmental protection issues is by encouraging students to engage in out-of-school activities, for example, joining different actions or events (Table 11). We need to emphasize that there are many local NGOs in Poland that promote the principles of sustainable development in different social groups. This provides teachers with great opportunities to promote these principles among their students. It is an attractive way that does not require much effort from teachers. Additionally, as proved by international research [33], the level of involvement and awareness of educational goals that are easily achieved by out-of-school activities translate into the effective implementation of these goals among students. 
Only 1in 10Polish language, human and social sciences, and foreign language steachers never use this approach to integrating environmental protection issues into their curricula (Table 12). More than $40 \%$ of Polish, science and natural sciences, and human and social sciences teachers declare that they very often encourage their students to engage in out-of-school activities connected with environmental protection. Over $16 \%$ of mathematicians never encourage students to engage in extra activities for the purpose of ESD, but slightly more than $30 \%$ very often do ( $44.44 \%$-sometimes).

Table 12. Encouraging students to take up out-of-school activities/engage in different actions and subject taught.

\begin{tabular}{|c|c|c|c|c|c|c|c|}
\hline & $\begin{array}{c}\text { Polish } \\
\text { Language }\end{array}$ & $\begin{array}{c}\text { Humanities } \\
\text { and Social } \\
\text { Sciences }\end{array}$ & $\begin{array}{c}\text { Foreign } \\
\text { Languages }\end{array}$ & Mathematics & $\begin{array}{l}\text { Natural } \\
\text { Sciences }\end{array}$ & $\begin{array}{l}\text { Information } \\
\text { and Technical } \\
\text { Subjects }\end{array}$ & Total \\
\hline Never & $10.00 \%$ & $8.96 \%$ & $10.81 \%$ & $16.67 \%$ & $6.98 \%$ & $0.00 \%$ & $9.50 \%$ \\
\hline Occasionally & $8.33 \%$ & $8.96 \%$ & $24.32 \%$ & $8.33 \%$ & $13.95 \%$ & $11.11 \%$ & $13.35 \%$ \\
\hline Sometimes & $38.33 \%$ & $40.30 \%$ & $32.43 \%$ & $44.44 \%$ & $37.21 \%$ & $33.33 \%$ & $37.39 \%$ \\
\hline Very often & $43.33 \%$ & $41.79 \%$ & $32.43 \%$ & $30.56 \%$ & $41.86 \%$ & $55.56 \%$ & $39.76 \%$ \\
\hline
\end{tabular}

\subsection{Relations between Ways of Integrating Environmental Issues into Curricula and Selected Variables}

Using Pearson's chi-square test, we tried to determine whether there are any statistically significant relations between independent variables and the ways that teachers introduce environmental protection issues into curricula. Statistically significant results arethose with $p<0.05$.

Analysis of the results reveals that there is a statistically significant correlation between including the issue of environmental protection into subject curricula and school location (Tables 13-15).

Table 13. Integrationof ESD-related topics during subject lessons and school location.

\begin{tabular}{ccccc}
\hline & \multicolumn{4}{c}{ Location } \\
\cline { 2 - 5 } & Village & Small Town & Big City & Total \\
\cline { 2 - 5 } & $\%$ & $\%$ & $\%$ & $\%$ \\
\hline Never & $2.34 \%$ & $2.94 \%$ & $5.88 \%$ & $3.31 \%$ \\
\hline Occasionally & $2.34 \%$ & $3.68 \%$ & $8.82 \%$ & $4.22 \%$ \\
\hline Sometimes & $20.31 \%$ & $29.41 \%$ & $42.65 \%$ & $28.61 \%$ \\
\hline Very often & $75.00 \%$ & $63.97 \%$ & $42.65 \%$ & $63.86 \%$ \\
\hline Total & $100.00 \%$ & $100.00 \%$ & $100.00 \%$ & $100.00 \%$ \\
\hline
\end{tabular}

Table 14. Chi-square tests.

\begin{tabular}{lccc}
\hline & Value & df & Asymptotic (Bilateral) Significance \\
\hline Pearson chi-square & $21.428^{\mathrm{a}}$ & 6 & 0.002 \\
\hline Likelihood ratio & 20.838 & 6 & 0.002 \\
\hline Linear relationship test & 16.344 & 1 & 0.000 \\
\hline N of significant observations & 332 & & \\
\hline \multicolumn{2}{c}{${ }^{2}$ 33.3\% of cells (4) havean expected frequency of less than 5. Minimum expected frequency is 2.25. }
\end{tabular}

Teachers in village schools more often implement environmental protection issues in their subject lessons. This may mean that in rural areas, where students have regular contact with nature, teachers are more aware of the needs of our planet and are more willing to include such issues as using renewable sources of energy or recycling in their daily curricula. It is unexpected that teachers working in cities, where there is intensiveanti-smog campaigning [33] and heavy use of renewable energy sources, less often introduce environmental protection issues into their daily lessons. 
Table 15. Symmetric measurements.

\begin{tabular}{llll}
\hline & & Value & Approximate Significance \\
\hline \multirow{2}{*}{ Nominal by nominal } & Phi & 0.254 & 0.002 \\
\cline { 2 - 4 } & Cramer's V & 0.180 & 0.002 \\
\hline \multirow{2}{*}{ N of significant observations } & 332 & \\
\hline
\end{tabular}

Another statistically significant relationhipis the relation between including environmental protection issues into curricula and thedegree of professional promotion (Tables 16-18).

Table 16. Coverage of ESD-related topics during subject lessons and level of professional promotion.

\begin{tabular}{cccccc}
\hline & \multicolumn{5}{c}{ Degree of Professional Promotion } \\
\cline { 2 - 6 } & Trainee & Contractual Teacher & Appointed Teacher & Chartered Teacher & Total \\
\cline { 2 - 6 } & $\%$ & $\%$ & $\%$ & $\%$ & $\%$ \\
\hline Never & 23.08 & 4.44 & 2.44 & 3.55 & 3.57 \\
\hline Occasionally & 0.00 & 8.89 & 4.88 & 29.59 & 28.87 \\
\hline Sometimes & 7.69 & 31.11 & 29.27 & 64.80 & 63.39 \\
\hline Very often & 69.23 & 55.56 & 63.41 & 100.00 & 100.00 \\
\hline Total & 100.00 & 100.00 & 100.00 & & $\%$ \\
\hline
\end{tabular}

Table 17. Chi-square tests.

\begin{tabular}{lccc}
\hline & Value & df & Asymptotic (Bilateral) Significance \\
\hline Pearson chi-square & $21.140^{\text {a }}$ & 9 & 0.012 \\
\hline Likelihood ratio & 14.363 & 9 & 0.110 \\
\hline Linear relationship test & 3.875 & 1 & 0.049 \\
\hline N of significant observations & 336 & & \\
\hline a $43.8 \%$ of cells (7) have an expected frequency of less than 5. Minimum expected frequency is 0.46.
\end{tabular}

Table 18. Symmetric measurements.

\begin{tabular}{llcc}
\hline & & Value & Approximate Significance \\
\hline \multirow{2}{*}{ Nominal by nominal } & Phi & 0.251 & 0.012 \\
\cline { 2 - 4 } & Cramer's V & 0.145 & 0.012 \\
\hline \multirow{2}{*}{ N of significant observations } & 336 & \\
\hline
\end{tabular}

As shown by the research results, the youngest teachers implement environmental protection issues into curricula the most often. This means that newly graduated teachers are the ones who are the most aware of the need to implement environmental protection. This, in turn, may mean that universities are training teachers to focus on ESD exercises, including environmental protection, using renewable energy sources, recycling, etc.

There is a statistically significant correlation between the level of education taught and the incorporation of the issue of environmental protection into subject curricula during additional classes (Tables 19-21). 
Table 19. Coverage of ESD-related topics during additional classes, for example, interest clubs, and type of school.

\begin{tabular}{cccc}
\hline & \multicolumn{3}{c}{ School Type } \\
\cline { 2 - 4 } & Lower Secondary & Upper Secondary & Total \\
\cline { 2 - 4 } & $\mathbf{\%}$ & $\%$ & $\%$ \\
\hline Never & 10.73 & 18.12 & 14.11 \\
\hline Occasionally & 12.43 & 24.16 & 17.79 \\
\hline Sometimes & 51.98 & 38.26 & 45.71 \\
\hline Very often & 24.86 & 19.46 & 22.39 \\
\hline Total & 100.00 & 100.00 & 100.00 \\
\hline
\end{tabular}

Table 20. Chi-square tests.

\begin{tabular}{lccc}
\hline & Value & df & Asymptotic (Bilateral) Significance \\
\hline Pearson chi-square & $13.771^{\mathrm{a}}$ & 3 & 0.003 \\
\hline Likelihood ratio & 13.807 & 3 & 0.003 \\
\hline Linear relationship test & 9.014 & 1 & 0.003 \\
\hline N of significant observations & 326 & & \\
\hline${ }^{\text {a }}$ 0.0\% of cells (0) have an expected frequency of less than 5. Minimum expected frequency is 21.02.
\end{tabular}

Table 21. Symmetric measurements.

\begin{tabular}{llcc}
\hline & & Value & Approximate Significance \\
\hline \multirow{2}{*}{ Nominal by nominal } & Phi & 0.206 & 0.003 \\
\cline { 2 - 4 } & Cramer's V & 0.206 & 0.003 \\
\hline \multirow{2}{*}{ N of significant observations } & 326 & \\
\hline
\end{tabular}

The result of the analysis shows that the practical integration of environmental protection issues into additional classes depends on the level of education taught - it is more often introduced by teachers in lower-secondary schools. This may result from the fact that extra classes in upper-secondary schools are focused on preparing students to take their maturity exam (in Poland, high school graduates take an obligatory exam, the so-called matura, which is necessary to enter university). Thus, teachers in lower-secondary schools have more time and opportunities to address the problems of sustainable development and environmental protection during their additional lessons.

The last statistically significant relation is between the integration of environmental protection issues into curricula by encouraging students to take up out-of-school activities/engage in different actions and school location (Tables 22-24).

Table 22. Encouraging students to take up out-of-school activities/engage in different actions and subject taught, and school location.

\begin{tabular}{ccccc}
\hline & \multicolumn{4}{c}{ Location } \\
\cline { 2 - 5 } & Village & Small Town & Big City & Total \\
\cline { 2 - 5 } & $\%$ & $\%$ & $\%$ & $\%$ \\
\hline Never & 4.69 & 11.76 & 13.24 & 9.34 \\
\hline Occasionally & 7.81 & 15.44 & 19.12 & 13.25 \\
\hline Sometimes & 39.06 & 34.56 & 39.71 & 37.35 \\
\hline Very often & 48.44 & 38.24 & 27.94 & 40.06 \\
\hline Total & 100.00 & 100.00 & 100.00 & 100.00 \\
\hline
\end{tabular}


Table 23. Chi-square tests.

\begin{tabular}{|c|c|c|c|}
\hline & Value & df & Asymptotic (Bilateral) Significance \\
\hline Pearson chi-square & $15.377^{\mathrm{a}}$ & 6 & 0.018 \\
\hline Likelihood ratio & 16.274 & 6 & 0.012 \\
\hline Linear relationship test & 13.284 & 1 & 0.000 \\
\hline $\mathrm{N}$ of significant observations & 332 & & \\
\hline
\end{tabular}

Table 24. Symmetric measurements.

\begin{tabular}{llcc}
\hline & & Value & Approximate Significance \\
\hline \multirow{2}{*}{ Nominal by nominal } & Phi & 0.215 & 0.018 \\
\cline { 2 - 4 } & Cramer's V & 0.152 & 0.018 \\
\hline \multirow{2}{*}{ N of significant observations } & 332 & \\
\hline
\end{tabular}

It turns out that, like in case of extra classes, teachers in village schools most often impartenvironmental protection issues by encouraging students to engage in out-of-school activities. This means that teachers feel responsible for the protection of the natural environment and are more engaged in activities toward using renewable energy sources, recycling, or pollution prevention than their fellow professionals in towns or big cities.

\section{Conclusions and Discussion}

Schools, as institutions for general education, are believed to have a responsibility to equip their students with the knowledge and commitment to make personally meaningful decisions and act accordingly to address the challenges posed by both lifestyle and societal conditions. Achieving this goal requires, among other things, the adequate integration of these 'challenges' into the school curricula [34,35]. The research results reveal that Polish teachers working with youth aged 13-20 years in schools in Malopolska are aware that it is necessary to integrate the problems of environmental protection into a didactic process. They realize it is necessary to equip students with knowledge and skills regarding their surrounding environment and some global environmental aspects (general condition, threats), as it determines the future condition of our natural world. It is particularly interesting and important that it is not only teachers of subjects dedicated to the environment, like biology or physics, who are aware of the need to communicate these issues and who indicate thatthey address them in their curricula in many ways.

It is very important that teachers try to include environmental protection topics in their subject lessons. Foreign language teachers seem to be the most aware in this area. A possible reason is that because they know foreign languages, they more often read foreign (other than Polish) publications about ESD: for example, the ones created by UNESCO experts. It is also worth noting the fact that while working with adolescent students, these teachers can assign homework which shapes language competencies and are, at the same time, connected with environmental protection issues. It is extremely important to model active research attitudes among students, conviction about individual responsibility for the environment, and awareness of the threats resulting from human activity. Students should choose their actions based on sustainable development principles. Thus, teachers are responsible for ensuring that students are aware of how their actions affect the natural environment. It is possible that teachers will shape the knowledge and attitudes of students by integrating environmental protection issues into their curricula.

The analysis of the results shows that the more experienced the teachers, the more willing they are to promote sustainable development. Perhaps training and additional education of teachers who want to be promoted effectively raise their awareness and expand their knowledge about ESD. It is also 
possible that teachers who have worked longer are more aware of the necessity ofintegrating issues into their curricula, as suggested by UN education experts. For more experienced teachers, it is also easier to adopt different initiatives, like integrating key environmental issues into their didactic practice.

Teachers are less willing to address environmental protection issues during their additional classes, for example, interest clubs. Giving up this method of integratingkey sustainable development problems into curricula may mean less effective education in the area of environmental protection.

We have presented the point of view of teachers regarding the integration of environmental protection issues into curricula, and the survey was conducted among educators in 1of the 16 administrative regions in Poland. It is worth looking at the research carried out in by Hidayah Liew Abdullah, Hamid, Shafii, Ta Wee, and Ahmad in Malaysia [1]. The results indicate that pupils' perception of the environment is overall high, and the location of the school does not significantly affect the pupils' perceptions of the environment. The majority of students define the concept of the environment as objects. In addition, the percentage of pupils who rationally regard the concept of the environment is also high. The perceptions of pupils on the need to protect the environment illustrate that the majority agree on the benefits it will impart to future generations. The environmental concepts are presented somewhat rationally and show the relationship between the environment and human beings. In conclusion, students' perceptions of the environment are positive; they can understand it rationally and know the nature of the natural disasters resulting from human actions.

It is also worth mentioning the research carried out in Mexico which indicated that official documents like general study plans, study programs of grades, and official students' textbooks include competences related to environmental education called 'competences for the coexistence', promoting harmonic relationships with others and with nature. Additionally, EE for sustainability was included as a transversal topic, with the expectation that participation will contribute to the graduate profile of basic education, indicating that students should promote and assume the care of health and the environment. Nevertheless, it is not clear how teachers are expected to implement EE in practice, meaning there is a lack of clarity inthe environmental theory that supports this curriculum [36].

Salmani, Hakimzadeh, Asgari, and Khaleghinez had conducted research in the field of environmental education in Iranian school curriculum [37]. The results show that the subjects presented at the highest frequency in sixth-grade social studies and science textbooks are ecology and human activities and the environment, respectively. Furthermore, human activities and the environment are more prominent in the science textbook rather than the social studies ones, although ecology is more prevalent in the latter. In terms of informational load and importance in these textbooks, ecology, the environment, and human activity are the main foundation of environmental education, respectively. In sum, in these textbooks, the three aforementioned bases have not been presented in parallel, and some modifications to the content of these textbooks are required to make them more understandable to the Iranian students.

The issue of integrating the key environmental protection aspects into curricula is also important in Serbia. In 2014, Stanišić and Maksić [38] published research results suggesting that students do not have enough knowledge to contribute to the development of a healthy lifestyle and environmental awareness. The latest changes in school policy and curricula confirm that the relevance of environmental education is recognized, but changes in school practice are yet to come. Also, Jukić [39], in his research, showed that ecological content currently dominates in the natural sciences among the school subjects. Additionally, both students and teachers graded the suitability of ecological content higher in relation to its current degree of representation inall school subjects. These results show that there is room and interest within the educational system (of both students and teachers) for the increase ine cological content in all school subjects. We should not expect young people to independently connect the pieces of information they receive from their teachers but should rather work on changing the educational system. The essential elements of ecology as a scientific discipline are so complex that, in order to reach a more comprehensive understanding, we cannot rely only on 
the natural sciences viewpoint. In other words, we need to teach ecology as a whole, as a system composed of proto-elements which appear in all school subjects throughout school curricula.

In their research, Molapo, Stears, and Dempster [40] indicated that, in Lesotho schools, the intended curriculum contains laudable goals with regard to learning in and about the environment. However, teachers interpret the curriculum in such a way that they teach mainly about the environment and never in the environment, and they seldom engage learners in activities in which they could develop positive attitudes that would encourage them to act with consideration of the environment.

As we can see, the adaptation of curricula to the aims of ESD is the object of many studies and scientific interest all over the world. Numerous research results prove that school curricula are crucial for promoting the principles of sustainable development.

\section{Recommendations}

Sustainable development aimsto ensure the improvement of the quality of life and economic progress without negatively affecting the environment o rreducing the availability of natural resources for future generations. According to UNESCO experts, sustainable development must be supported by properly planned and effectively implemented education. For ESD principles to be taught in practice and, first of all, known, the issues of sustainable development must be an obligatory part of teacher training programs. Teachers must realize that these principles are necessary and must know how to practically integrate sustainable development issues into their curricula.

In Poland, there are numerous discussions on introducing environmental protection to universities as an obligatory subject by means of a regulation issued by the Ministry of Science and Higher Education. It would be compulsory for economic, human sciences, and art studies, environmental engineering, and, first of all, for all pedagogy curricula (all teaching specializations). It seems to be a reasonable move, as teachers' actions would then be intentional (not incidental), and they would be more willing to integrate sustainable development content into their curricula (not only curricula of biology, chemistry, or natural sciences).

Results of the analysis show that foreign language teachers more often and more willingly address sustainable development issues during their subject classes. This means that other teachers may not have enough knowledge in this area, which, in turn, may mean they do not know of the publications addressing the problems of sustainable development. Therefore, teachers need to receive materials and tools in Polish, which would help them to understand the assumptions and principles of sustainable development and become familiar with the ways of incorporating ESD-related issues into their curricula.

Education for sustainable development in Poland is supported by EU funding. In 2016, the Ministry of Environment accepted rankings in two competitions of the Infrastructure and Environment Operational Programme for Measure 2.4 Environment protection and the promotion of ecological habits, sub-measure 2.4.5 Information and education activities in the area of environmental protection and effective use of natural resources. Forty-four applications were submitted to the competition POIS/2.4.5/2/2015 type b: Building the potential and integration, with a total value of 44 million PLN in EU support. Seventeen applications, for a total value of 18 million PLN, received s positive formal and quality assessment. The financial allocation of the competition was about 13 million PLN. The projects involve education through new media. They are examples of implementing good practices which significantly increase students' and teachers' awareness and knowledge about sustainable development issues.

In some Polish schools, compliance with sustainable development principles is seen as a school mission. Sustainable development topics are not only addressed in subject curricula but also in competitions, projects, the organization of the school premises, and the engagement in the protection of the local environment. It is a very good example of the practical implementation of sustainable development principles, as it not only raises awareness in students, teachers, and the local community but also enables the active promotion of sustainable development. 
It is very important to connect the efforts made by schools to promote sustainable development with out-of-school activities, e.g., in cooperation with local communities. Such integrated actions will be more effective not only for students but also for the community [40].

Only joint activities of schools, institutions that educate and train teachers, the local community, and media are likely tolead to the full incorporationof environmental protection issues in school curricula. Therefore, we need to make every effort to enable such activities [41].

Author Contributions: Conceptualization, A.M. and I.O.; Data curation, A.M.; Formal analysis, I.O.; Methodology, A.M., I.O.; Writing - review \& editing, K.W.-S.

Funding: This research received no external funding.

Conflicts of Interest: The authors declare no conflict of interest.

\section{References}

1. Alrikabi, N.K.M.A. Renewable Energy Types. J. Clean Energy Technol. 2014, 2, 61-64. [CrossRef]

2. Boeve-de Pauw, J.; Gericke, N.; Olsson, D.; Berglund, T. The Effectiveness of Education for Sustainable Development. Sustainability 2015, 7, 15693-15717. [CrossRef]

3. Abdullah, N.H.L.A.; Hamid, H.; Shafii, H.; Ta Wee, S.; Ahmad, J. Pupils Perception Towards the Implementation of Environmental Education Across Curriculum in Malaysia Primary School. J. Phys. Conf. Ser. 2018, 1049, 012098. [CrossRef]

4. Pearce, D.; Barbier, E.; Markandya, A. Sustainable Development.Economics and Environment in the Third World; Earthscan: London, UK; Washington, DC, USA, 2010.

5. Kuzior, A. Dekada Edukacjidla Zrównoważonego Rozwoju. Zeszyty Naukowe Politechniki Ślaskiej 2014, 72, 87-100.

6. Leicht, A.; Heiss, J.; Byun, W.J. Issues and trends in Education for Sustainable Development; UNESCO Publishing: Paris, France, 2018.

7. Frisk, E.; Larson, K.L. Educating for Sustainability: Competencies \& Practices for Transformative Action. J. Sustain. Educ. 2011, 2, 1-20.

8. United Nations Educational, Scientific and Cultural Organization. Education for Sustainable Development: Learning Objectives; United Nations Educational, Scientific and Cultural Organization: Paris, France, 2017.

9. Jutvik, G.; Liepina, I. (Eds.) Education for Change: A Handbook for Teaching and Learning Sustainable Development; Gsndrs: Riga, Latvia, 2007.

10. Ocetkiewicz, I.; Tomaszewska, B.; Mróz, A. Renewable energy in education for sustainable development. The Polish experience. Renew. Sustain. Energy Rev. 2017, 80, 92-97. [CrossRef]

11. UNESCO. Educational Module on Conservation and Management of Natural Resources; Unesco-UNEP International Environmental Education Programme: Paris, France, 1986.

12. Tomaszewska, B. Sustainable Energy: Human Factors in Geothermal Water Resource Management. In Advances in Human Factors in Energy: Oil, Gas, Nuclear and Electric Power Industries; Springer: Cham, Switzerland, 2018.

13. Tomaszewska, B.; Rajca, M.; Kmiecik, E.; Bodzek, M.; Bujakowski, W.; Wątor, K.; Tyszer, M. The influence of selected factors on the effectiveness of pre-treatment of geothermal water during the nanofiltration process. Desalination 2017, 406, 74-82. [CrossRef]

14. Tomaszewska, B.; Pajak, L.; Hołojuch, G. Energy and environmental analysis of disposing of concentrate by injecting it back into the deep geological formation. Desalin. Water Treat. 2017, 69, 316-321. [CrossRef]

15. Robinson, K.; Aronica, L. Creative Schools: The Grassroots Revolution That's Transforming Education; Penguin Books: New York, NY, USA, 2016.

16. UNESCO. Second Collection of Good Practices Education for Sustainable Development; UNESCO Associated Schools: Paris, France, 2009.

17. UNESCO. Global Action Programme on Education for Sustainable Development; UNESCO Publishing: Paris, France, 2018; Available online: http:/ / unesdoc.unesco.org/images/0024/002462/246270e.pdf (accessed on 16 May 2018).

18. Szempruch, J. Nauczyciel w warunkachzmianyspołecznej; IMPULS: Kraków, Poland, 2013. 
19. Palka, S. Nauczyciel jako badacz pedagogiczny [w:] J. Kuźma, J. Morbitzer (red.); Naukipedagogicznew teoriiipraktyceedukacyjnej: Kraków, Poland, 2003.

20. Schön, D.A. The Reflective Practitioner. How Professionals Think in Action; Basic Books: New York, NY, USA, 1987.

21. Giroux, H. Theories of Reproduction and Resistance in the New Sociology of Education. Harv. Educ. Rev. 1983, 53, 257-293. [CrossRef]

22. Liston, D.P. On Facts and Values. An Analysis of Radical Curriculum Studies. Educ. Theory 1986, 36. [CrossRef]

23. Parsons, T. The School class as a Social System. Some of its Functions in American Society. Harv. Educ. Rev. 1959, 29, 297-318.

24. McLaren, P. Schooling as Ritual Performance: Towards a Political Economy of Educational Symbols and Gestures; Rowman \& Littlefield: Boston, MA, USA, 1986.

25. Bardziejewska, M. Okres dorastania. Jak rozpoznać potencjał nastolatków? In Psychologiczne portrety człowieka; Brzezińska; Brzezińska Anna, I., Ed.; GWP: Gdańsk, Poland, 2015.

26. Bee, H.; Boyd, D. Lifespan Development; Pearson: New York, NY, USA, 2011.

27. UNESCO. Transforming Our World: The 2030 Agenda for Sustainable Development; UNESCO Publishing: Paris, France, 2015.

28. Babbie, E. The Practice of Social Research; Thomson Wadsworth: Belmont, MA, USA, 2001.

29. Kivunja, C.; Kuyini, A.B. Understanding and Applying Research Paradigms in Educational Contexts. Int. J. High. Educ. 2017, 6, 26-41. [CrossRef]

30. Christensen, B.; Johnson, L. Educational Research: Quantitative, Qualitative, and Mixed Approaches, 4th ed.; SAGE Publications: Thousand Oaks, CA, USA, 2011.

31. Commission Regulation (EU) No 651/2014 of 17 June 2014 Declaring Certain Categories of Aid Compatible with the Internal Market in Application of Articles 107 and 108 of the Treaty (CELEX: 32014R0651). Available online: https: / / www.paih.gov.pl/files/?id_plik=11991 (accessed on 18 May 2018).

32. Hattie, J. Visible Learning for Teachers: Maximizing Impact of Learning; Routledge: London, UK, 2012.

33. Wilczyńska-Michalik, W.; Wilczyński, M. Air pollution in Cracow-A glance into the future from a historical perspective. Geobalcanica 2017, 79-82. [CrossRef]

34. Dalelo, A. Loss of biodiversity and climate change as presented in biology curricula for Ethiopian schools: Implications for action-oriented environmental education [Etiyopyaokullarindayeralan biyolojimüfredati\{dotless\} konulari\{dotless\}ndaniklimdeǧişikliğivebiyolojik-çeşitliliğinyokolmasi: Eylemyönelimliçevreeğitimineyönelikçi\{dotless\}kari\{dotless\}mlar]. Int. J. Environ. Sci. Educ. 2012, 7, 619-638.

35. Paredes-Chi, A.A.; Viga-de Alva, M.D. Environmental education (EE) policy and content of the contemporary (2009-2017) Mexican national curriculum for primary schools. Environ. Educ. Res. 2018, 24, 564-580. [CrossRef]

36. Salmani, B.; Hakimzadeh, R.; Asgari, M.; Khaleghinezhad, S.A. Environmental education in iranian school curriculum, A content analyses of social studies and science textbooks. Int. J. Environ. Res. 2015, 9, 151-156.

37. Stanišić, J.; Maksić, S. Environmental education in Serbian primary schools: Challenges and changes in curriculum, pedagogy, and teacher training. J. Environ. Educ. 2014, 45, 118-131. [CrossRef]

38. Jukić, R. Environmental education in grammar school curricula [Intercurriculäreransatzzurökologischenerziehung und bildung]. Soc. Ekol. 2014, 22, 221-245.

39. Molapo, L.; Stears, M.; Dempster, E. Interpretation and implementation of the environmental education curriculum: A case study of three lesotho schools [Interpretering en implementering van die omgewingsopvoeding-kurrikulum:'n gevallestudie van drieskole in lesotho]. Acta Acad. 2012, 44, 202-229.

40. Reed Jonson, J.A. Education for Sustainable Development in Eco-Schools. Contextualised Stories from England and South Africa; Lambert Academic Publishing: Saarbrucken, Germany, 2013.

41. Petty, G. Teaching Today. A Practical Guide, 3rd ed.; Nelson Thornes Limited: Chentelham, UK, 2004.

(C) 2018 by the authors. Licensee MDPI, Basel, Switzerland. This article is an open access article distributed under the terms and conditions of the Creative Commons Attribution (CC BY) license (http://creativecommons.org/licenses/by/4.0/). 